\title{
Iris Murdoch's The Black Prince: A Valorization of Metafiction as a Virtuous Aesthetic Practice
}

\begin{abstract}
Having a self-conscious narrator who is obsessed by the question of art-truth relationship, The Black Prince is the paradigm of metafiction among Iris Murdoch's works. A discourse about the problems of writing fiction, the novel actually exposes the ontological status of all literary fiction, i.e. its quasi-referentiality, its indeterminacy and its existence as a linguistic world. This paper argues that more than being a thematic concern, metafiction is the integral part of The Black Prince whose fragmented form mirrors the complexity of reality. It concludes that such a full-fledged metafictional project does not resonate with the anti-fictional convictions but aspires to validate metafiction as the perfect moral form of fiction.
\end{abstract}

Key words

Metafiction; truth; art; self-conscious narrator; reality

Good art explains to us how the world is changing and it judges change, it's the highest wisest choice of morality, it is something spiritualwithout good art a society dies. It's like religion really-it's our best speech and our best understanding - it's a proof of the greatness and goodness which is in us.

Murdoch-Art and Eros: A Dialogue about Art

Iris Murdoch's novels have always been analyzed mainly in terms of her philosophical ideas and The Black Prince is no exception. The criticism it has aroused 
takes it widely as the epitome of Murdoch's oeuvre for its thematic concern over the capability of erotic love to purvey man with a glimpse of eternal truth and the efficacy of art to express that truth; in short, for its emphasis on the interconnection of love, beauty and truth. Nussbaum (2004) sees the novel a reflection on the double nature of love; a depiction of the tension that exists between selfish and selfless love: the former depriving man of the full access to reality, the latter granting him with moral vision. Nicol (1999) considers the novel an adventure into the nature of the past-present relation, demonstrating that only after one accepts the past's significance $s /$ he can have a clearer vision of the present. Hornbuckle takes the narrative as the major proof of Murdoch's employment of "the literary text as a locus for investigating the idea of intersubjective truth." pinpointing Murdoch's interest "in using literature to explore the relationship between the aesthetic value and ontology," this critic discusses that The Black Prince is an art object that in inviting readers "to determine its aesthetic quality," evokes in them "an understanding that points beyond itself" (2006: 221).

Recognizing the firm adherence of the novel to the complexity of reality, other critics have examined it for the responsible literary techniques; Rowe (2007) underlines its dependence on "the perception of multiple perspectives simultaneously" as a sign of its opposition to the unitary vision of fanaticism. Building her discussion heavily on Northrop Frye's theory of modes, Hague argues that it is structurally comic hence a credit to Murdoch's "conviction that the comic mode is the most appropriate vehicle for the novel" (1984: 145). Bellamy (1977) acknowledges the formal complexity of the novel just to indicate Murdoch's experimentation with the most appropriate vehicle for the novel to catch hold of the new concept of reality.

Identifying the countervailing forces in The Black Prince's formal and thematic levels, this paper aims at exploring further its raison d'être. Dissecting its stylistic features in light of the major literary movements, it shows that The Black Prince has a parodic aesthetic that helps Murdoch draw on the established literary conventions to suggest the ethics of narrative. The inclusion of the four postscripts by the dramatic personae purveys the novel with enough leverage to undermine the validity of the story of Bradley, the first-person narrator, and disrupt the form it seems to advocate as truthful; this study discusses that while challenging the possibility of a single coherent reality and the objective representation, the novel places metafiction over conventional fiction for its ethical value.

"Metafiction is a term given to fictional writing which self-consciously and systematically draws attention to its status as an artefact in order to pose questions about the relation between fact and fiction," explains Waugh (1984: 2). Although nowadays associated with postmodernism, the instances of "fiction that includes within itself a commentary on its own narrative [...] identity" have been traced back to the nascent stage of the novel; the texts frequently mentioned in this regard are, enumerates Wolter, British novels like Clarissa, Tom Jones and Tristram Shandy, and American texts including the romances of Hawthorne and Melville (1994: 67). Critics, however, have recognized an ontological difference 
between this traditional practice and the contemporary one: the former self-reflexivity was to reinforce the suspension of the disbelief, while the new version is to capture the complexity of truth. As Wolter notes, being a backlash to the growing belief in the expiration of the novel clearly proclaimed in Barth's "The Literature of Exhaustion" or Sukenick's "The Death of The Novel" (1994: 67), postmodern metafiction is a new discourse "to involve the readers in questioning the legitimation of fiction or even reality. It helps to blur the distinction between the fact and fiction as both are expressed through the fragmentary language and the subjective reception of data" (78). The metafictional impulse in The Black Prince is even for a greater ambition: to introduce metafiction as the only possible truthful discourse.

In comparison to Murdoch's other novels, the question of "what is truth?" is more central in The Black Prince which credits many versions of events and relationships. Driven by his epistemophilla to understand the obsessive uncanny events that cost him life imprisonment, Bradley writes an ironical artefact that being full of gaps defies any certainty about what actually happened. Portraying a permutation of relationships, "The Black Prince: A Celebration of Love" is Bradley's attempt to justify his past experience convincing himself and his audience that his love for Julian was transcendental enough to compensate for his suffering and to inspire him to the original truthful art he has longed for all his life. As a self-conscious narrator, he talks of two versions of love (low Eros and high Eros) stressing that only high Eros, the spiritual desire for truth, ignites great art and grants us enough wisdom of reality to overcome, what Whitehouse calls, "the horror of death, anger, bitterness and paralyzing incomprehension" (2001: 61). His account, nevertheless, loses its footing when the characters' postscripts expose his delusive life.

Approaching the story through many perspectives, Murdoch's The Black Prince, rather than any of its segments, deserves the title of truthful fiction. The challenge each perspective sets to the others' reliability both indicates the complexity of reality and sharpens the metafictional edge of the novel. A complicated textual project with the central story of the bizarre erotic engrossment of Bradley with Julian, the twenty-year old daughter of his friend, the prolific novelist Arnold Baffin of whose murder he is finally convicted, the narrative proves that true love, very different from its romantic kind in Bradley's story, is respectful of the other and thus an index of fuller humanity. Through Bradley's inattention to the others' feelings and the gaps in his narration, Murdoch indicates that modern moral degeneration is due to man's inability to associate virtue, truth and love, whose collaboration, she expresses in The Sovereignty of Good, is essential for man's perfection. As depicted in the case of Bradley, the pursuit of one of these principles without the others never leads man to a better vision of reality.

The dramatis personae's modifications of Bradley's account are a way to highlight that "life is horrible, life is a muddle, and one's existence has no pattern" (Bove 1993: 6). Spotlighting the other aspects of events untouched or unknown by Bradley, they expose the delusion of Bradley's confidence in his absolute freedom 
to impose a pattern on his aleatory life. As Bove's interpretation of accidents in Murdoch's world suggests, the interspersion of the story with them bespeaks of Murdoch's virtuosity in polishing her image of reality and propelling the plot concurrently (6). Aware of the difficulty to offer the jumble of his past as a work of art, Bradley appears to be like the enlightened Dora who felt as "a priestess, dedicate now to a rite" (Murdoch 1958: 244); however; the doubts on his reliability highlight his resemblance to the selfish Dora who decided to "play the witch" (205). Deluded by his freedom, he takes his narrative to be the realization of his literary ambition which has inhibited him to "profane the purity of a single page with anything less than what is perfectly appropriate and beautiful, that is to say, with anything less than what is true" (Murdoch 1973: xii). However, in light of the others' view of his account, it is beyond doubt that he is actually a victim of Murdoch's plot.

Bradley is conscious of the indispensable part of chance in life - "life is horrible, without metaphysical sense, wrecked by chance, pain and the close prospect of death" (Murdoch 1973: 55) - and foregrounds in his foreword the contingent as the only hostile force against man's will: "[a]lways a world of fear and horror lies but a millimeter away. Any man, even the greatest, can be broken in a moment and has no refuge" (xviii). However, he is ignorant of the role that the will of others and the effect of the past on the present play in any individual existence. Murdoch's The Black Prince underlines these ignored aspects of reality. The sudden reappearance of Christian, his ex-wife, Francis, Christian's brother, Priscilla, his sister, after years in his life are examples of the tenacity of the past on the state of the present. No matter what he does to keep them out of his life, they leave their footprints on the sharp turn his life takes towards its crisis after years of considerable passivity. The problem with Bradley is that he feels he can be the master of the moment no matter what his past was and what chance has in reserve for him. In this sense, he is very similar to Charles Arrowby, the narrator of The Sea, the Sea, who writes a narrative oscillating between diary and memoir to accentuate his own control over his life. Rachel tries to dissolve this delusion in Bradley when she says, "[o]ne is responsible for one's action, and one's past does belong to one. You can't blot it out by entering a dream world and decreeing that life began yesterday. You can't make yourself into a new person overnight..." (310).

The dramatic ironies in Bradley's account and its incongruity to the others' view of events makes the novel the field of discursive struggles of conflicting views each as powerful and convincing as the others. Moral, scientific, materialistic, subjective, and artistic modes of perceiving the world are competing, with no success, to prove themselves the best container for truth. Besides the diegetic level, the novel's narrative elements are the locus of conflict; the realistic and modernist opposite views on reality struggle to determine the plot, setting, characterization and narration.

The Black Prince is full of challenges to the coherency of the plot, a convention observed in realism. On the extradiegetic level, that is the level of the editor's narration, the plot is both textually and chronologically fragmented. It is spo- 
radic as various people authorize its segments: successively Bradley the author, Bradley the intradiegetic narrator, Bradley the author, Christian, Francis, Rachel, Julian, the editor. Moreover, it features a dislocated chronology since the editor as an omniscient narrator annexes to the text of the events that happened years ago to his alleged friend the comments he extracted later from the other participants in those events. The editor finally provides an ending to his indirect narration by telling what happened to Bradley and casting judgments on the author's view in his postscript. In this way, the earlier events (those in Bradley's story) are related much later in the editor's narration.

On the hypodiegetic level, i.e. "The Black Prince: A Celebration of Love," the plot is more self-consciously incoherent. It acts as the mise en abyme for the encompassing plot of the editor. The obvious gaps and blank spaces among the segments of the editor's text are echoed in deliberate pauses Bradley makes for characterization, setting, addressing his "dear friend," predicting the reactions of his readers and even amending his descriptions. In introducing almost all the characters including himself, Bradley interrupts the plot to highlight his narrating role: "[p]erhaps I might pause here yet again for a moment to describe myself" (Murdoch 1973: 3). Other examples are when he tries to give an image of Priscilla: "[a]t this point it is necessary for me to give some account of my sister, Priscilla, who is about to appear upon the scene," or even her husband Roger: "I will not attempt a lengthy description of Roger. He too will appear in the story in due course" (43). Once he stops quoting a letter to Arnold to delineate a more detailed picture of his sitting-room: "I have not described this important room adequately yet" (35). Bradley's anticipation of the further description of two of the objects in his room pauses the plot to add a comic tone to his setting, turning it into a parody of the realistic setting than its straight imitation: "upon the chimney piece $[\ldots]$ stood the little items, china cups and figures, snuff boxes [...] some of which I may describe later since two at least of these objects play a role in the story" (36).

These interruptions are multiplied when Bradley pauses to speak to his narratee whom he refers to as "my dear friend": "perhaps at this point in my story, my dear friend, I may be allowed to pause and speak to you directly" (Murdoch 1973: 54). Sometimes, he sustains his account of the past to debunk the reader's inference: "[t]he reader, especially if he has not had the experience I have been describing, may feel impatient with the foregoing lyricism. 'Pshaw!' he will say, 'the fellow protests too much and intoxicates himself with words. He admits to being a thoroughly repressed man, no longer young. All he means is that he suddenly felt intense sexual desire for a girl of twenty. We all know about that.' I will not pause to answer this reader back, but will go on as faithfully as I can to recount what happened next" (173). Or when he says, "[w] hat a common girl, the reader may say: naive, ignorant, thoughtless, not even particularly beautiful. Or else you have misdescribed her" (171). Anxious to give a fair picture of Arnold, Bradley engages in retouching his image: "I pause here to say another word or two about my protégé Arnold Baffin. I am anxious (this is not just a phrase, I feel 
anxiety) about the clarity and justice of my presentation of Arnold, since this story is, from a salient point of view, the story of my relations with Arnold and the astounding climax to which these relations led" (8). The paradox is that despite all these distractions from the plot, he still believes that he is not going to delay his narration: "The 'story' shall never be long kept in abeyance" (54).

In addition to the lack of realistic coherency, the plot covers an ironical time span through developing a hypodiegetic-extradiegetic pattern. Neither is it a short slice of life as in modernism nor of a biographic length as in realism. The hypodiegetic plot encompasses a period of nearly ten days in the life of Bradley when he felt he was struck by true love. In his foreword and postscript, this period expands to range from Bradley's childhood till he gets incarcerated for murder. The extradiegetic plot expands the time span further to Bradley's death and even the time of the novel's publication when his desire to publish an ingenious work of art is fulfilled posthumously. Presuming the editor to be the enlightened Bradley, who by surpassing the self-portraying work of the selfish Bradley finally achieves the truthful form of art in the actual novel of The Black Prince, the time span is just a slice in Bradley's life from his birth to this success. The plurality of views that Bradley the editor allows in his work makes it an everlasting incarnation of unrepresentability of truth, a true art which according to him "is not cosy and it is not mocked. Art tells the only truth that ultimately matters. It is the light by which human things can be mended. And after art there is, let me assure you all, nothing" (Murdoch 1973: 364). In this sense, The Black Prince is the story of birth, death and resurrection of the author indispensable for the formation of an ingenious art; its time span, then, is, to use Bradley's metaphor for his eternal love for Julian, an eternal "loop".

Chronology is another convention parodied here. On the hypodiegetic level, Bradley is so deeply committed to chronology that he sometimes postpones the account of his thoughts in the middle of an action: "[t]he telephone rang in the empty house. It was office hours, afternoon. I was looking at my well-shaven upper lip in the telephone box mirror, and thinking about Christian. What these thoughts were I will explain later. I could still hear that demonic laughter" (Murdoch 1973: 73). He even modifies the function of the foreword and uses it to supply the essential details about his childhood in order to minimize flash backs. This regulation is, nevertheless, disturbed on many occasions when his sudden prolepses and analepses raise his status to that of an omniscient narrator as he can interfere in chronology by respectively bringing forward or postponing the narration of a story-event. ${ }^{1}$ On the extradiegetic level, chronology, as it has been noted earlier, was subordinated to the format of the novel. The editor's statements in his foreword and postscript subvert any sense of chronology Bradley built in his manuscript. Having Bradley's narrative followed by the other characters' postscripts and embraced by his own portions, he turns them all into interlaced "frame-stories" which are arranged based on the logic of story-telling than a linear temporal sequence.

The absence of chronology on these two levels of the plot has textual manifestations; both Bradley's manuscript and the editor's text are fragmented. The 
former through the blank spaces saved between various portions of narration dividing Bradley's story in three main parts, the latter through the various headings that compartmentalize the text into nine main sections (I regard contents page of the novel as part of the editor's text). Such intermittence defies the formation of the traditional, continuous linear plot notwithstanding the fact that the plot in linguistic art is always linear since words follow each other on the space of pages. Beside the enigmatic codes (BP-A, BP-A* ... BP-M*) appearing here and there at the page-bottoms, these textual fragmentations illuminate the fictionality of plot: the fact that there is an author, a craftsman behind the mechanism of the novel, who deploys certain established artistic conventions to make the commonplace more fascinating and worthy of attention.

Being a fragmented structure that flamboyantly draws on both literary realism and modernism for its coherency and chronology, The Black Prince's plot is eye-catching on two other grounds: the beginning and the ending. Instead of the modernist technique of open-ending plots and the realistic method of linear succession of events from a set beginning to a definite ending, it replaces multiple beginning and ending. Playing with these two conventions as postmodern fiction does, it ends in a stunning flexible plot. In the hypodiegetic narrative, Bradley starts his narration with the metafictional question of beginning: uncertain of how to start his tale, he comments: "there are indeed many places where I could start. I might start with Rachel's tears, or Priscilla's. [...] In a complex explanation any order may seem arbitrary. Where after all does anything begin? That three of the four starting points I have mentioned were casually independent of each other suggests speculations [...] upon the mystery of human fate" (Murdoch 1973: 1). The last part of this quotation is metafictional evidence that the novel and indeed any postmodern fiction has still a claim to mimesis, that uncertain beginning and ending are the consequence of imitating the actual reality not the outcome of radical adherence to the modernism ideal of "art for art's sake."

Bradley chooses to starts his story with an unexpected visit of Francis who came to inform him of the return of Christian from America as a rich widow. However, the unusual information he supplies in his foreword suggests that the beginning is actually much earlier when he and his sister spent their childhood in their parents' shabby paper shop. This is supported by the clear evidence that his foreword has been written before the main text and has interdependent relationship with it: the foreword ends in his arrangements to depart to Patara. The subsequent reference to it in the main text indicates that the forward is part of the story, "as I have explained, I was about to leave London" (Murdoch 1973:1). Yet another beginning offers itself since it is the editor's foreword that launches the novel. Encountered by so many possible beginnings, the reader is jolted into its conventionality.

Similarly the ending is multiplied in an outstanding, conscious way. Bradley's story ends in vagueness and his shock for being accused of the murder of Arnold to whose house he has rushed after Rachel's call of distress. It is in his postscript that he explains in a nutshell what actually happened to him then and afterwards 
despite his stress that his story ended where it did: "[t]he first days were a maelstrom of confusion, misunderstandings, incredulity. Not only could I not believe what had happened, I could not conceptualize it. However I am not going to tell anything more of this as a story. The story is over." (Murdoch 1973: 329). Written basically as comments on Bradley's story, the four postscripts, moreover, open new dimensions in his supposedly finished story. They break the seal of ending by acting as "afterwards," revealing what happened to other characters in the meanwhile; Christian has married Heartbourne and gone into the cosmetic business, owning a Salon. Rachel is living alone as Julian has got married to Oscar Belling, whose relationship to her appears to be broken off for good in Bradley's story. Julian is now a poet who has her own aesthetic theory. Francis turns to be a successful psychological consultant who is going to write the results of his psychological study of Bradley's case in a forthcoming book. Furthermore, the editor's short account of Bradley's last days in prison when he was diagnosed with ever-growing cancer still provides another ending to the novel.

Parodying the conventional endings in tragedies, the tragic death of Bradley, a common egoistic man, enables the plot to assimilate the biographical air of realistic plots. However, a glimpse of his life from childhood till death (a pathetic fate reported in another level of narrative), The Black Prince mocks the realistic necessity for closure. The burning issue of the identity of the editor along with his words about the eternality of art in the last page of the novel self-reflexively defies any literal sense of closure to the plot: "[a]nd Bradley Pearson's story, which I made him tell, remains too, a kind of thing more durable than these" (Murdoch 1973: 364). A linguistic piece of art, The Black Prince never ends. On the contrary, in its playful dealing with the plot elements both thematically and structurally, it produces a formless form, a huge ironic construct typical of postmodernism that entertains its readers for generations to come.

In The Black Prince, setting is mainly London but expands to include Ealing (Baffin's), Bristol (Priscilla's), Croydon (Bradley's parents' shop) and finally an unidentified beachside village in which Patara is located. Rendered in a realistic adumbration, it strikes us off and on with its precision when one expects the least precision. Such uncommon treatment of setting surely is not arbitrary. Resonating with duality, it seconds The Black Prince to condemn the blinding nature of love while celebrating its redemptive power. More effective than any direct statements, the setting reflects the change of vision Bradley undergoes when experiencing a selfless love for others. As he drives Julian to their haven, Patara, he sees the "very blue twilight between fat flowery chestnut trees" and "the full moon like a dish of Jersey cream above a barley field which was still catching the light of the sun" (Murdoch 1973: 260). Such precise vision of nature despite his nagging anxiety about the future is justifiable only in light of the illuminating effect of his love.

Generally speaking, the picture he portrays of his surroundings despite its adherence to Murdochian trend of huge details is almost always too ethereal to be realistic. Two reasons seem to be involved: firstly, to intensify its symbolic significance and make the story myth-like; Murdoch just identifies those features 
of the neighborhoods which attribute certain connotation to the story. Bradley describes his dwelling as:

a ground-floor flat in a small shabby pretty court of terrace houses in North Soho, not far from the Post Office Tower, an area of perpetual seedy brouhaha. [...] My "rooms" were all at the back. My bedroom looked onto dustbins and a fire escape. My sitting- room onto a plain brick wall caked with muck. [...] A sunless and cosy womb my flat was, with a highly wrought interior and no outside. Only from the front door of the house, which was not my front door, could one squint up at sky over tall buildings and see above the serene austere erection of the Post Office Tower. (Murdoch 1973: 2)

The strong thematic resonance of the Post Office Tower becomes striking when the frequent references to it are dovetailed with dominant image of womb in the rest of the narrative. As he divulges to Francis, Bradley frequently dreams of his parents' paper shop in his childhood; he even dreams of it as he falls asleep on a quay in Bristol leaning his head on a ship's hull. For him, the hollowness of the ship evokes the image of the shop, a woman, and dead animals in cages. Both in the story and later in his own postscript, Francis interprets these as the symbols of the womb and symptoms of Barley's Oedipus complex. Emphasizing on his perverted sexuality, Francis even interprets his obsession with the Post Office Tower as his homosexuality believing that Bradley was in love with Arnold: "[w] hen I say that Bradley Pearson was in love with Arnold Baffin I would not be understood to be making any crude statement. We are dealing with the psychology of a complicated and refined person" (346), even him (Francis):"I would not, and indeed need not, use his ill-concealed love for me as evidence of his perverted tendencies" (348).

Since the love that Bradley feels for Rachel and later for Julian is most of the time a self-conceited love that doubles his ego, he sees the natural surroundings in presence of them as paradise. His description of Baffin's garden on the day he twice kisses Rachel reminds one of the Garden of Eden:

The Baffins' garden was not big, but in the flush of early summer it seemed endless. A dotting of fruit trees and ferny bushes amid longish red-tufted grass obscured the nearby houses, obscured even the creosoted fence. Only a hint of pink rambler roses between the trunks suggested an enclosure. The garden was a curved space, a warm green shell smelling of earth and leaves. (87)

This description goes well with the vignette he depicts of the natural surroundings of Patara, the secluded, beachside cottage he takes Julian to after their elopement:

Julian [...] set off across the sort of huge courtyard of flat seaworn stones which divided us from the house. Here mauve sea cabbage and blue vetch 
and cushiony pink thrift was growing in profusion and wild yellow tree lupins sprawled their starry leaves and pallid cones of blossom about upon the stripey concentric stones of the natural pavement. [...] The exact whereabouts of the paradise I shall for many reasons conceal, but amateurs of the British coastline may hazard their guess. (emphasis added 267-268)

The setting develops an ethereal air, secondly, to deprive the reader of the selfsatisfying joy of cracking its descriptive codes. Murdoch does not want her readers to be interpreters. She wants them to be just the observers of the complexity of human psyche and the novel's capacity for truth. That is why she lets the significance of the story multiple in the postscripts where the characters' various interpretations block any further possibility of reading. Familiar but unidentifiable places make the setting dual; pointing to the simultaneous presence of the realistic and modernist trends, they turn the setting to an ironic postmodern device apt for a self-reflexive work which tends to put the world of fiction on par with that of reality.

A postmodern device, setting here builds up the metafictional impulse of the narrative, by producing déjà $v u$ effect which makes the readers more conscious of the act of reading and attracts their attention to the artistic, rhetorical aspect of the novel. On the occasion Rachel takes Bradley to her house for lunch, Bradley feels so close to her that he kisses her. As he leaves the house, the setting, viz. the garden and house, is blurry and dark framing a person looking out of a window of the house: "[a] figure was sitting in an upstairs window, sitting up half reclined upon a window seat, or even it seemed upon the window sill itself. Without seeing the face except as a blur I recognized Julian, and felt an immediate pang of guilt at having kissed the mother when the child was actually in the house" (Murdoch 1973: 92). Later a rather similar scene is portrayed when Bradley distressed by the urgency to see Julian rushes to Ealing and prowling in front of Baffin's feels: "[a]s I stood there in that thick oppressive urban dusk breathing the breath of fear, smelling the dunes of dust, I became aware of being looked at by a figure standing in the long unlighted landing window of the house I was studying. I could see the figure framed in the window and the pallor of the face regarding me. It was Rachel" (242). Such scenic similarity is, indeed, the novel's way to upset the established convention of love triangle in classical fiction by entangling one lover with two spiteful beloveds.

Characters in The Black Prince owe their existence to an equal contribution of realism and modernism. A counterpart of Jake in Under the Net, Bradley is another indefinable, anti-hero that shares this status more conspicuously with almost all the other characters. In contrast to the cast of the Under the Net whose complexity of consciousness oozes through the gaps and contradictions in Jake's netlike narrative, here the characters have been given a chance in the space of their postscripts to come into the centre and challenge the authenticity of the central consciousness. Equally significant, every one form Francis, Christian, Priscilla, to Arnold, Rachel, Julian and Bradley acts as a key figure in propelling the plot 
in the direction it takes. The discrepancies between Bradley's story and the other characters' comments are just a way to illuminate the psychological complexity of all the active characters.

Bradley Pearson is indeed one of the most complex characters portrayed in English literature. At the beginning of his narration, he pauses to describe himself: "I am thin and tall, just over six feet, fairish and not yet bald, with light fine silky rather faded straight hair. I have a bland diffident nervous sensitive face and thin lips and blue eyes. I do not wear glasses. I look considerably younger than my age" (Murdoch 1973: 3). Throughout the rest of the narration, however, this description sounds really shaky. He is "a trifle deaf" as he cannot hear what Francis is saying at his doorstep (3). His poor eyesight is obvious in his frantic attempt to take Priscilla who has taken a bottle of sleeping pills to hospital when he addresses Arnold thus: "II can't read the blasted telephone number. Can you read the number?' 'I always said you needed glasses"' (54). These symptoms of old age identified in his foreword to be exactly fifty-eight and repudiated in his undue stress on his youth even his transformation to a much younger age under the spell of his love for Julian signifies a lot about his characterization; his final surrender to write is more due to his selfish desire to escape death than a proof of the realization of his poetics that has kept him from being a prolific writer like Arnold. As an author, Bradley is an egoist who tries to preserve his own self through love and art.

A lonely fifty-eight desperate perfectionist writer who fails to publish any worthy piece of work, he easily fumbles in meddles of love justifying it essential for the visitation of his muse. Trying to convince his reader that the Black Eros, the demon of love, is actually his demon of art when he notes that at the time of the story he was possessed by a huge black power that would certainly reward him with the art he had so anxiously waited for, he anticipates that his manuscript despite whatever faults that it may still have is that reward. The discrepancies in his narration and the larger textual project of the novel demonstrate that, far from meeting his aesthetic principle that calls any piece of writing art only if it creates an objective replica of truth, his text is an attempt to aggrandize his humiliated self.

A self-conscious narrator-author, Bradley postulates that he is writing to tell the truth of love stories which, he believes, has been ignored in almost all previous stories. However, the noticeable pauses that he takes to describes himself and his characters signify how much it is impossible. For instance, he portrays Francis to be "stout (the raincoat failed to button) and not tall, with copious greyish longish frizzy hair and a round face and a slightly hooked nose and big very red lips and eyes set very close together. He looked, I later thought, rather like a caricature of a bear. Real bears, I believe, have eyes rather wide apart, but caricatured bears usually have close eyes, possibly to indicate bad temper or cunning" (emphasis mine 3). Such caricature-like and funny descriptions parody the realist technique of direct presentation. Employing direct presentation, they show that it is a pointless device since always marred by the narrator's consciousness. 
Paradoxically, Murdoch achieves a truer characterization when she highlights its subjective disposition: no images of appearance remain the same throughout Bradley's story; sometimes, they even resemble each other to certain extent as characterizations superimpose just like when people undergoing emotional turmoil look different or see others differently; Priscilla and Rachel resemble each other in their marital miseries; in depicting the depressed Priscilla, Bradley says, "[s]he looked so pitiful and ugly, I reached across and pulled the curtain a little. Her swollen face, the scene in the dim light, reminded me of Rachel" (Murdoch 1973: 49). Arnold's complexion is of different shades in different situations: "There was a general lack of colour. Something of an albino?" Later on, it is described as "pale brown" next as being "with any emotion [...] uniformly pink, as if a pink light had been switched onto it" (61). Francis and Christian look different when Francis reveals their Jewish identity of which Bradley was ignorant: "I stared at Francis. When you find out that somebody is Jewish they look different. I had only after many years of knowing him discovered that Hartbourne was a Jew. He immediately began to look much cleverer" (118). About Jewish Christian, he comments, "[o]f course I could see now that she was Jewish: that curvy clever mouth, that wily rounded-off nose, those veiled snaky eyes. She was as handsome as her dress, a queen in Israel" (134).

Julian changes so much in different scenes that she crosses the gender border and appears as both a boy and a girl. Introduced first in the story, she looks like a young man. In fact, Bradley takes her as one: "I noticed with only a little surprise and interest the figure upon the other side of the road of a young man who was behaving rather oddly. He was standing upon the kerb and strewing flowers upon the roadway, as if casting them into a river" (Murdoch 1973: 30). Even when closer Bradley realizes that the figure is Julian, her features appear to him boyish: "[e]ven at close quarters she still slightly resembled a boy, tallish, dour, who had just cut himself in a premature attempt to shave his first whisker" (32). It is this boyish look that prevails finally on Bradley to make love to her: "[s] he was dressed in black tights, black shoes, she wore a black velvet jerkin and a white shirt and a gold chain with a cross about her neck. She had posed herself in the doorway of the kitchen, holding the sheep's skull up in one hand" (280).

Such fluidity in characterization throughout the whole novel disparages direct presentation for its inability to convey the complexity of people's characters; the best way to render it, Murdoch trusts, is through the characters' actions and their relationships. In her attempt to reconcile the two extreme views of characters as either people or words, Rimmon-Kenan defines characters as "nods in the verbal design of text as well as non-verbal abstractions in the story" (2002: 35). The impression that the reader has of such textual nods in The Black Prince is that they cannot be subsumed under any general labels which constitute the basis of direct characterization. The non-verbal abstractions formed in the reader's mind are notably multi-faceted.

Aware "that people often have completely distorted general ideas of what they are like. Men truly manifest themselves in the long patterns of their acts, 
and not in any nutshell of self-theory" (Murdoch 1973: xi), Bradley cannot characterize his cast objectively. An egoist, he theorizes people's personality to keep his own psyche self-conceited and intact. Always involved in patternmaking, he gives people a label then interprets their actions in that light. For him everybody belongs to a stereotype: Arnold to the group of the uncommitted, best-selling writers that write for the sake of profit; Rachel to the group of selfsacrificing wives who never are bold enough to disengage themselves totally from the shackles of unhappy matrimony. Priscilla to the cluster of those who have spent their youth in delinquency so deserve to be doomed to an unjust, unhappy married life; Christian is one of the steel-willed, scheming women who are always after the exertion of their own will-to-power; Francis is just one of those pathetic soft-hearted men who bereft of dignity easily latch onto others to scrape a living; Julian is one of the new generation who being mainly cynic or hedonist rise against the conventions and the morals of their society without giving it a second thought. However, the unexpected reactions of these people to the turn of events creates a centrifugal force that never lets the various shots of them converge into any unified, stable psychological portraits. Even the characters' attempt in their postscripts to amend their portrayals in Bradley's story instead of clearer pictures makes them hazier.

Similar to the other personae, Bradley himself cannot be summarized into a single coherent image. He is nearly sixty years old but looks younger. The complexity of his character is crystalized in the inconsistencies between his decisions and his actions. As a participant in the events, he is seen acting the very things he obsessively made his mind to avoid. At the outset of his story, he firmly decides to ignore both Francis and Christian. He sends them letters to tell them stay away from his life emphasizing his disinterest in them. But the development of the plot shows that it is he who needs them; he directly goes to see Christian the moment she calls him and trusting Francis with everything he lets him take care of the depressed Priscilla! Another instance can be traced in his relationship with Julian; although time and again he convinces himself of the impropriety of making love to her, he eventually does it in a harsh way and on an inappropriate time when Francis acquaints him with the news of Priscilla's suicide.

Such unpredictability is at the heart of all the characters' complexity. None of the personae are like themselves the next moment they appear in Bradley's narrative. This surprises Bradley the character who assumes that people's actions are justifiable on that basis of their fixed personalities. Christian and Arnold fall for each other; Rachel tells Arnold of Bradley's interest in her; Roger succumbs to grant Priscilla the items she desires to her; Julian leaves Bradley suddenly unnoticed at the middle of night despite her apparent tender love for him. Francis enacts different roles, as an unwelcome nuisance, a doctor, a buffoon, a parasite, a psychologist, a buddy, a page, a witness to his innocence. Such complexities are doubled in postscripts where Murdoch ingrains in the novel an ironical mode suggesting that the unpredictability of human beings is due to their egoism: in his postscript, the editor states: 
Whatever Bradley himself would have thought or done, it is difficult not to exclaim at the small-mindedness of these writers. Each piece is self-advertisement, ranging from the vulgar to the subtle. Mrs Heartbourne advertises her salon, 'Dr' Marloe his pseudo-science, his 'consulting rooms', his book. Mrs Baffin polishes the already much publicized image of herself as a suffering widow [...] Mrs Belling advertises herself as a writer. (Murdoch 1973: 361-362)

Similar to these postscript writers, Bradley highlights himself in his narrative. His story is ironically the celebration of "self-love". His mistake in taking his disguised egoism in his love for Julian even for Rachel as his muse costs him his sister's life; he fails to respond morally to the desperate emotional needs of Priscilla who despondent of her married life turns to him.

Bradley's characterization appears much more complex when an air of mystery is woven around the editor's identity. Although the editor signs his forward as P. Loxias and accepts to be the very friend Bradley frequently addresses in his manuscript, the dramatis personae's various accounts of his identity in their postscripts make the reader suspicious about his real existence. His own confession to be the only friend and companion of Bradley in his last days of suffering from cancer, his self-alleged twofold intention "to give to the public a work of literature" and "to vindicate the honour of my dear friend, to clear him, briefly, of the charge of murder" (Murdoch 1973: 362), his strong support of Bradley, his sharp critique of the others and his similar writing style to Bradley's provide a sound basis to believe that he is Bradley in disguise. In writing such an iconoclast form of the novel, Bradley the editor projects the whole process of artistic creation from its conception to its consumption; a sun-seeker who emerges from the cocoon of his old self dying before his own eyes, his very person embodies that artistic creation is first a moral strive for the author. A character, narrator and author, Bradley succeeds to simulate the truth when he assigns himself the role of editor (and by implication reader and critic) as well publisher of the novel. Unparalleled in the history of metafiction, such amalgam of roles by one persona truly makes The Black Prince Iris Murdoch's magnum opus.

Again, The Black Prince prefers neither of the realistic or modernist tradition over the other in narration. A collection of texts, it allows both the omniscient and first-person narrators have their parts in narrating. Bradley's obsessive comments on the features and functions of great art, its essential difference from fantasy and its fundamental aspiration for perfection while taking his narrative to be the representative of such an art make him a self-conscious narrator. Indeed, what makes Bradley a perfect postmodern narrator, who ironically just constructs a version of reality while striving to imitate it, includes: his deliberate pauses to describe the characters and cast a self-criticism on his role as a narrator, his failure to keep his omniscient consciousness from his narrating consciousness, his intermittent addressing his implied reader, his anticipation of the criticism his narration could arise, his sensitivity to plot elements (the opening scene, climax and ending) and 
setting in short his full-awareness of the difficulty of telling and writing a truthful account of a lived experience. His endorsement of irony as the only viable device to catch truth and his stress on the inevitability of art to reflect on itself gives currency to metafiction as a truthful art. It is particularly evident when he styles his narrative a piece of art: "[m]y book is about art. It is also, in its humble way, a work of art: an 'art object', as the jargon has it; and may perhaps be permitted, now and then, to cast a look upon itself" (Murdoch 1973: 55).

Enlightened through the hard task of creative writing, Bradley realizes what Scholes identifies at the heart of all metafiction: "[there] is no mimesis, only poiesis. No recording. Only constructing" (1975: 7). The interesting point about such narrators is that, by focusing on the relation of mimesis and truth, they reveal aspects of human experience absent in the account of traditional narrators. Their mingling of fact and fiction, states Wolter, involves readers in "a discourse about the fictionalization of reality" and encourages them to decide over the question of truth for themselves (1994: 78). Examining Brown's Wieland and Irving's "Rip Van Winkle," Wolter stresses that instead of "an organizing, detached, omniscient, and reliable narrator" the narrative centre in the former is occupied by "a self-consciously, uncertain fabulist who uses the freedom of her creative imagination," and in the latter by a narrator-editor "who leaves it to the reader to construct a reading of the several texts he has collected" (78-79). Similarly, a fabulist-editor looms large in The Black Prince. In his foreword, Bradley laments the difficulty of telling his story from a pure narrating consciousness not affected by the knowledge gained through the course of events. His impatient incessant reference to the overhanging of a fateful incident plus his tendency to complement his information with parenthetical statements as well as the integration of his general ideas in the present tense in his narration not only vindicate his lamentation but also suggest that being an omniscient narrator is always a temptation to any narrating consciousness which, naturally egoistic, primarily aspires to self-defence through the privilege of absolute knowledge.

The ironical role of Bradley as the narrator is more prominent if we assume The Black Prince as a bildungsroman. A male writer obsessed by the question of love, Bradley writes of his own experience trying to be objective. A couple of years later, more wiser by this artistic practice, his solitude in prison and his exposure to music, he decides to publish a more truthful version of it by giving space to some of the characters' view of the course of events as well as his own enlightened self. The result is the unusual multi-layered format of the novel and an ironical narrator who under the guise of an editor-publisher projects the evasiveness of truth. Bradley acts as fabulist and an omniscient narrator at both hypodiegetic and extradiegetic levels. On the former, he is the narrator-author who thinks that love is the only incentive and truthful topic for great art. On the latter, he is the editor-publisher who narrates the story of his useless attempt to capture the essence of love.

Taking the nom de plume of P. Loxias allows Bradley to serve a double function that is highly conducive to the presentation of the unrepresentability of truth. 
The tension that such Janus-faced narrator generates allows the novel to echo the Murdochian belief in the redemptive power of art when it acknowledges the immanence of chance, contingency and diversity in life. Another rationale behind Murdoch's characterization of Bradley as both an autodiegetic and a heterodiegetic narrator is to disrupt the established binary opposition between "historian" and "romancer" which Brown defines as follows: "the observer [...] who carefully watches, and faithfully enumerates the appearances which occur, may claim the appellation of historian. He who adorns these appearances with cause and effect $[\ldots]$ performs a different part. He is a dealer, not in certainties, but probabilities, and is therefore, a romancer" (Wolter 1994: 75). Portraying them too ready in pre-judgments, she indicates that to be a pure historian or romancer is a myth as each is the other to some extent.

Embracing Bradley's account and the postscripts of his pseudo-counterparts within the editor's consciousness, the novel mocks the convention of reliability. Lacking a trustable start and an objective conclusion, The Black Prince parodies, as critics believe Faulkner's Sound and Fury does, the "customary demand for a conventional novel" (Wolter 1994: 75). Duplicating the editor's status for Julian who has the similar privilege of reading all the other postscripts before writing her own, Murdoch metafictionally shows that reliability is an irrelevant issue in criticizing a text since nobody can be reliable. Condemning her for the self-aggrandizing overtone of her account, the editor subjects implicitly his own views to the same criticism. Allowing six narrations to compete for the trust of the reader with no success, The Black Prince is undoubtedly a postmodern metafiction which, housing many characters with a passion for writing at one time or the other in their lives, involves the reader in a playful discourse about truth and the way it is constructed. Crossing the generic borders of many literary categories (characters take it as a drama, autobiography, even a novel), it is an intensive selfreflexive novel that devotedly celebrates the moral value of metafiction.

\section{Notes}

$1 \quad$ For an account of "prolepsis" and "analepsis" see Rimmon-Kenan (2002: 48).

\section{References}

Bellamy, Michael O. (1977) “An Interview with Iris Murdoch”. Contemporary Literature 18, 129 140.

Bove, Cheryl Browning (1993) Understanding Iris Murdoch. Columbia: University of South Carolina Press.

Hague, Angela (1984) Iris Murdoch's Comic Vision. Cranbury: Susquehanna University Press.

Hornbuckle, Calley A. (2006) "Exploring Aesthetic Perception of the Real in Iris Murdoch's The Black Prince". In: Tymieniecka, Anna-Teresa (ed.). Logos of Phenomenology and Phenomenology of the Logos. Dordrecht: Springer, 221-235. 
Murdoch, Iris (1958) The Bell. London: Vintage.

Murdoch, Iris (1973) The Black Prince. London: Chatto.

Nicol, Bran (1999) Iris Murdoch: The Retrospective Fiction. New York: St. Martin's.

Nussbaum, Martha Craven (2004) “"Faint with Secret Knowledge': Love and Vision in Murdoch's The Black Prince". Poetics Today 25, 689-710.

Rimmon-Kenan, Shlomith (2002) Narrative Fiction: Contemporary Poetics, $2^{\text {nd }}$ ed. London: Routledge.

Rowe, Anne (ed.) (2007) Iris Murdoch: A Reassessment. New York: Palgrave Macmillan.

Scholes, Robert (1975) Structural Fabulation. Notre Dame: University of Notre Dame Press.

Waugh, Patricia (1984) Metafiction: The Theory and Practice of Self-Conscious Fiction. London: Methuen.

Whitehouse, J. C. (2001) "Men, Women, God, and So Forth". Logos: A Journal of Catholic Thought and Culture 4, 54-75.

Wolter, Jürgen (1994) “"Novels are ... the most dangerous kind of reading': Metafictional Discourse in Early American Literature". Connotations: A Journal for Critical Debate 4, 67-82.

Sara Soleimani Karbalaei is a PhD Researcher in English Literature in the Department of Studies in English, University of Mysore, India. She has published a few articles in peer review journals on the works of Iris Murdoch, James Joyce and J. M. Coetzee. She did her MA in English Literature at Shiraz University, Iran. She is an Iranian national.

Address: Sara Soleimani Karbalaei, $34^{\text {th }}$ Alley, North Abouzar, Marvdasht, P.O. Box: 73717-16398, Fars, Iran. [email: Sara_Soleimani_karbalaei@yahoo.in] 
